\title{
Karin Johannisson
}

\author{
Kroppen i den moderne medicin \\ - et historisk perspektiv på moderniteten
}

Om den psykoanalytisk orienterede læge Georg Groddeck, der havde sit virke ved 1900-tallets begyndelse, berettes der, at når han måtte overtage et usædvanligt kompliceret sygdomstilfælde, som andre læger ikke kunne hjælpe, lod han patienten indlægge på sin klinik nogle dage uden at de mødte hinanden. Kroppen blev befriet for spændinger med varme bade, milde lavementer og let kost.

Han satte sig så en dag ved sygesengen. Tæppet blev fjernet. Han placerede sit øre mod patientens mave og lyttede i flere timer uden at sige et ord. Han følte og klemte på leddene. Han lugtede til patientens ånde, nogle gange til kønnet. Til sidst når hans lytten, følen og sniffen var slut, begyndte han at tale og stille spørgsmål. Efter en stund kunne han foreslå en diagnose, ofte uventet og som indebar at den syges symptomer var symbolske udtryk for et indre jeg som gestaltede sig på den plastiske krop.

Den diagnostiske metode var altså at lade patienten tale gennem kroppens indre lyde og tegn, et sprog som gik forud for det verbale, og at aflytte dette sprog med sine egne sanser. Sygdommen var et system af tegn, der kunne opfanges gennem en andens krop. ${ }^{1}$

Hundrede år tidligere ligger fremvæksten af den moderne klinik. I Michel Foucaults Klinikkens Fodsel gives på et langt mere abstrakt og generelt plan en beskrivelse af, hvordan den syges krop tolkes gennem forskellige tegn og symptomer. En liste, som den kunne have set ud omkring år 1800, kan gøres lang: Puls, varme og åndedræt, øjne, tunge og hud, spyt, sved og urin, hoste, hikke og latter, kramper, rystelser og gispen, konstitution, mimik og gestik. Kategorierne for kroppens tegnsystem er mange, og er historisk set skiftende i flere retninger. Dels ændres de legitime former for det subjektive sygdomsudtryk, dels forflyttes lægens øje i relation til nye kundskabsteoretiske bevægelser og sociale kategorier, så som køn, klasse, race og typer. Når f.eks. Kretschmer hævdede at sygdommes karakter kunne aflæses direkte på kroppen i overensstemmelse med faste typologier, kom dette til at styre mange 1900-talslægers første syn på patienten. 
Centralt for Foucaults ræsonnement er adskillelsen mellem symptom og tegn. Selv om hvert symptom er et tegn, er hvert tegn ikke et symptom. Her er altså en adskillelse. Mens symptomet er, peger tegnet hinsides det selv, det udtrykker noget. Symptomet er tegnets morfologiske skelet. Det som forvandler det til et tegn er en tilstødende aktivitet, det tolkende blik. Symptomet bliver til et tegn, når det udsættes for et blik, der ordner, forklarer og klassificerer (Foucault (2000), 141-43). Centralt i Foucaults ræsonnement er endvidere forskydningen, ikke bare fra symptom til tegn, men også fra tegn til det betegnede. Lægens blik kom til at fokusere på sygdom som en afgrænset enhed og blev vent væk fra det syge menneske som en helhed.

Denne adskillelse mellem tegn og symptom er grundlæggende i den moderne medicin. Symptom defineres som sygdommens manifestation som den opleves af patienten selv, tegnet er sygdommens manifestation sådan som lægen registrerer den. Symptomet er subjektivt, tegnet er objektivt. ${ }^{2}$ Den erfarne læge kan altså forvandle det subjektive/individuelle til noget objektivt/generelt ved at se, hvad patienten ikke kan se. For at gøre dette må han nærme sig den syge krop på en nærgående måde. Han kan føle, lytte, banke, lugte, smage. Han kan vende og dreje patienten, lægge sit hoved mod hendes bryst eller mave, bede hende skille på benene, stå foroverbøjet eller ligge i fosterstilling, gabe op, strække tungen ud, lukke øjnene, hoste og trække vejret dybt ind. Han kan gå ind gennem kroppens åbninger og se ind i mørke hulrum. Han kan udtage væsker og væv fra kroppen og undersøge dem i laboratoriet. Alle disse aktiviteter lokker tegn frem, objektive data, som leder ham ind i sygdommens sande krop.

Men denne differentiering mellem subjektive symptomer og objektive tegn var knapt nok tydelig før 1800-tallet. Den er også delvist en illusion.

Dels kan symptom og tegn være sammenfaldne; da er også patientens og lægens blik sammenfaldne. Dels kan tegnets objektive status diskuteres. Den moderne læge kan komplettere de umiddelbart sansebetingede teknikker for kropsundersøgelse med en række sofistikerede procedurer, for at få kroppen til at tale tydeligere: Røntgen, mikroskopi, ct-skanning og ultralydsanalyse. Resultaterne kaldes objektive, fordi de kan reproduceres af enhver uddannet læge. Men i fortolkningen medtager han et spektrum af tavs og underforstået kundskab $i$ form af sanseerfaringer og kropserindring, forskellige grader af træning og sensibilitet, såvel som indskoling i bestemte teoretiske modeller, der beror på forskellige kulturelt bundne normer og forestillinger. Han ser det han vil se, eller det han forventer at se (dette kan enkelt illustreres med at en 1700-talslæge og en 1800-talslæge så forskellige ting gennem det samme mikroskop og med blikket rettet mod samme objekt; i moderne tid kan f.eks. en retsmedicinsk obduktion have samme effekt, afhængigt af hvilken tolkning man udlægger af dødsårsagen). 
Men endnu vigtigere: tegn er ikke tegn fordi det er lægen der tolker dem, men fordi de er meningsbarende, bærer på mening. Også for patienten kan symptomerne være tegn (straf, prøvelse, forkert livsstil)(King (1968).

På Foucaults klinik er der ikke mange talende, oplevende og fornemmende individer, det være sig patienter eller læger. Det, der savnes i hans teori om den moderne medicins gennembrud, er netop også et systematisk studium af medicinens praksis. Man skulle forestille sig, at det netop er praksissen, der ligger til grund for det kliniske blik: Undersøgelse, læsning og tolkning af symptomer. Hvis dette var tilfældet, skulle historien se noget anderledes ud. I stedet for at den talende krop ville være fortrængt af medicinens øje ved at blive objektiveret og sorteret i færdige kategorier, ville den blive fremhævet. I stedet for at klinikkens fortællinger skulle udgå fra den døde krop som retrospektivt facit, ville de handle om de levende kroppe. Det kropslige møde mellem læge og patient er grundlæggende i medicinsk praksis (Svenaeus (1999), 45).

Hvis man tror, at kroppen taler, må man udvikle teknikker til at lytte til den. Mit mål er at spore sådanne kundskabspraksisser i medicinen. Hvad ved vi om kroppen - patientens og lægens - i medicinens praksis? Hvilke var de konkrete teknikker til at nærme sig den syge krop med? Hvilken type berøring var tilladt? Hvordan blev det muligt, at patienten kunne klæde sig af for lægens granskende blik? Hvordan var lægens krop, og hvordan anvendte han den i kommunikationen med patienten? Hvordan trænede han sine sanser: Blikket, hørelsen, følelsen, lugtesansen og smagssansen? Hvordan kunne subjektive sanser forvandles til instrumenter for objektiv kundskab? Og til sidst: Hvordan kunne det være at kroppen, i løbet af 1900-tallet, blev trængt ud af det medicinske møde?

\section{Kroppen i det medicinske møde før 1800}

Frem til 1800-tallet byggede lægens formåen til at identificere en sygdom på tre teknikker: At lytte til patientens egen beretning, at observere sygdommens tegn på kroppens yderside og - mere sjældent - at undersøge kroppen manuelt. $^{3}$

Patientens egen beretning var den centrale kilde, når man stillede en diagnose. Det indebar, at det medicinske møde kunne finde sted uden at lægen traf patienten, f.eks. per korrespondance. Sygdomsberetningen skabte et subjektivt portræt af sygdommen, som placerede patientens fornemmende krop i centrum. Denne oplevende krop gav patienten fortolkningsretten i forhold til sygdommen. Nyere medicinhistorie plejer også at beskrive dette netop som den afgørende forskel på førmoderne og moderne medicin: 
Patienten betragtedes som en person - et subjekt - og ikke som et objekt (at forestille sig patienten som et autonomt jeg i moderne forståelse er dog misledende) (Se f.eks. Porter \& Porter (1989). Dette indebar, at følelser, angst, erindring, tolkning var en del af symptombeskrivelsen og umulig at separere fra den. I det hele taget kan det beskrives som en slags vidneteknik, hvor patienten er sit eget vidne ved at erindre og som en narrativ teknik, hvor hun kan gestalte sygdomserfaringen ved at forstørre, formindske, sortere fra eller lægge til. Den lyttende læge trækkes ind i det drama, som patienten lader sig udspille. I denne funktion, observerer eller eksaminerer han ikke kroppen.

I denne lyttende funktion går han også over grænserne mod folkelige forestillingsverdner og kan føres meget langt væk fra sin egen medicinske forståelse. I den fascinerende Geschichte unter der Haut (1987) beskriver den tyske kropshistoriker Barbera Duden de kvindelige sygdomsforestillinger som møder den tyske 1700-talslæge Johannes Storch via patienternes beretninger og som tvinger ham til at gå på kompromis med kropsbilleder af meget fremmed art. Med blikket rettet mod sygdommen som netop beretning, kan eksemplerne på lignende pragmatiske dialoger gøres uendelige.

Den anden teknik til at stille diagnoser med, var observation. Lægen granskede ydre tegn på patientens krop: Holdning, bevægelse, hud, hår, tunge, øjexble, kropsvæskernes lugt og farve. Termen inspektion anvendes somme tider for at lade blikket feje hen over en afgrænset kropsflade. Heller ikke her handler det om berøring af kroppen. Ansigtet spillede en central rolle som bærer af et rigt tegnsystem. Systematisk ansigtslæsning - fysiognomik - var fra gammel tid en hjælpevidenskab til at bedømme individets inderside via ydersiden. Teknikken skabte en række skarpe sygdomskarakteristikker - fra melankolikerens eller hypokonderens typiske ansigter til dødens nøgne slutkonturer: "næsen skarp, øjne og tindinger indsunkne, ørerne kolde og sammentrukne, ansigtsfarven bleggrøn, gråsort eller blygrå" ". Et signalement af 1700-talsmodellen er på samme måde en meget detaljeret beskrivelse et stærkt individualiseret ansigt. Som patognomik (hvordan lidelser gestaltes i ansigt og på krop) blev teknikken vigtig i den medicinske konsultation; den lærte lægerne at tænke visuelt og gjorde dem bevidste om en række sproglige, metodologiske og kommunikative spørgsmål.

Den observerende diagnostiske metode tillod, til forskel fra den narrative, at lægen drog konklusioner, der var bundet til hans eget blik. Samtidig byggede den, ligesom den narrative, på en grundlæggende empatisk dimension. Patienten observeredes som en person. Krops- og smertesprog var vigtige indslag $i$ diagnosen (det er tankevækkende at vi er kommet til at betragte netop dette individuelle smertesprog med mistænksomhed - som et sprog, frigjort fra selve sygdommen og dermed muligt at forkaste som en kulturelt skabt konstruktion). 
Den tredje teknik var eksamination, kropsundersøgelse. Men den betyder ikke aktiv undersøgelse med henblik på at spore organforandringer i kroppens indre. Den begrænsedes $\mathrm{i}$ almindelighed til en eneste sans: Følesansen. Lægen kunne f.eks. føle på pulsen for at bestemme den kvalitativt (altså ikke kvantitativt ved at tælle pulsslagene). Var den hård, svag, hakkende, ujævn? Han kunne aflæse kropstemperaturen ved at lægge hånden på patientens hud. Huden kunne også berøres for at bestemme dens karakter i overensstemmelse med temperementslærens skema. Varm, kold, tør våd? Nogle gange registreredes porøs, læderagtig og knopret hud, gåsehud, pergaments- eller papirhud.

Direkte kropsberøring var altså meget begrænset. Patienten var fuldt påklædt. Før inspektion eller okular besigtigelse, kunne visse dele af kroppen afdxkkes, men aldrig større partier samtidigt (Theile (1855), 13). Også terapeutiske forholdsregler styredes af bestemte dekorumregler for den afdækkede hud. Ved åreladning på en mandlig patient måtte ærmet straks rulles ned igen, på en kvindelig måtte intet blod være synligt på huden (Fissell (1993)). Tanken om at bede en patient om at klæde sig af, for at lade sin nøgne krop blive gransket af lægens hånd og blik, var endnu fremmed.

\section{Medicinens erotiske krop}

Grundene til at berøring med kroppen blev undgået var flere. Lige siden antikken var medicin, til forskel fra kirurgi, tankens - ikke håndens - arbejde. Lægen var en tænker, ikke en berører (Porter \& Porter (1989), 75). Hans kompetence måtte hvile på teoretiske forhold, for at han ikke skulle blive blandet sammen med andre kategorier af medicinske udøvere. Berøring truede med at underminere hans værdighed og placere ham på højde med kirurgen, hvis kompetence byggede på mesterlære og en håndværksmæssig måde at nærme sig kroppen på, med manuelle og instrumentelle teknikker. Under lægeuddannelsen rørte den lægestuderende ikke selv ved den syge krop, og endnu mindre ved den døde krop i forbindelse med dissektion; det var kirurglærlingens opgave.

At nærme sig patientens krop med sin egen syntes, i overensstemmelse med den indlærte rollefordeling, at være lavt og modbydeligt. Det ubehagelige ved den intime kropsberøring vender ofte tilbage som et særskilt aspekt ved lægegerningen. Lægen må "indimellem trænge ind i de ækleste huler" konstaterede en svensk læge i 1830'erne, og den legendariske Laennec - stetoskopets opfinder, som mere end nogen anden symboliserer den sansebundne kropsundersøgelse - beskrev den svedige, lugtende patientkrop som "modbydelig" (Illmoni (1837); Duffin (1998)). Skidt og stank kom før 
hygiejne. Ikke bare som et aspekt af sygdom, men også som metaforer for den socialt stigmatiserede krop. Dette gælder i endnu højere grad smitte.

Selv om alt dette var stærkere, skal skam og moralske hindringer overfor kropsundersøgelsen alligevel diskuteres. Lægens og patientens sociale stilling og værdighed markerede, uden tvivl, bestemte grænser for berøring. Så længe lægens virksomhed ikke legitimeredes af videnskabens neutrale blik, lå hans troværdighed $\mathrm{i}$ hans individuelle moral og mandlige selvbeherskelse. I den hippokratiske etik var forbudet mod seksuel udnyttelse af patienten een af fem grundregler (sammen med forbud mod dødshjælp, abort, kirurgi samt tavshedspligt). Samme forbud mod seksuel berøring er gennemgående i alle medicinske regelsystemer endnu i 1800-tallet. Lægen må under ingen omstændigheder gøre mødet med patienten til "en tjeneste for sine lyster", skriver en svensk læge i 1870erne; i mødet med sine kvindelige klienter "bør han vise sig kold som is og hård som marmor" (Mesterton (1872-3), 16). Det er en formaning, der illustrerer det erotiske bliks nærvær og at grænsen mellem empatisk og anden form for intimitet, opfattedes som problematisk. Beskyldninger for seksuel udnyttelse har altid været anvendt for at skille sig af med medicinens outsidere, og de har spillet en bestemt rolle i den videnskabelige medicins bortvisningsstrategier. En række af sådanne tilfælde er juridisk dokumenteret.

I lægens professionalisering spillede en nødvendig objektivisering i netop denne betydning altså en vigtig rolle; (et aspekt som mærkeligt nok sjældent er blevet diskuteret). Både patientens og lægens subjektive kroppe måtte holdes uden for det medicinske møde. Kropsundersøgelse som legitim indtrængen i den private kropssfære, forudsætter professionel distance. Lægens hånd på patientens krop er følende, ikke kærtegnende; blikket er sagligt, ikke sanseligt. Som en moderne læge udtrykker det: I den kliniske konsultation læses kroppen uden visse egenskaber, f.eks. æstetiske kvaliteter. Medicinens kroppe er ikke bløde, smukke eller erotiske (Baron (1992), 39).

Historisk set kan patientens forestilling om sin egen krop som en privat sfære, hvis grænser ikke må krænkes, diskuteres. Mange har hævdet at "den private krop" er en moderne opfindelse, og at det først var under 1800-tallets anden halvdel behovet for en sådan kropslig intimsfære kom til udtryk, i form af f.eks. forskellige soverum, undertøj og den nøgne krops intrikate tildækkelse. Den tyske antropolog Hans Peter Duerr har tværtimod hævdet, at skam over den nøgne krop er en del af menneskets natur og altså ikke et resultat af civilisationens disciplinering af den "naturlige" krop. ${ }^{5}$

Intimiteten fandtes også i konsultationens rumlige indramning. Centrum for den medicinske praksis var hjemmet, enten patientens eller lægens. For gynækologiske konsultationer var undersøgelse i hjemmet en regel i det mindste frem til århundredeskiftet 1900. Ofte var lægen samtidig gæst 
og sommetider ven af huset. Netop dette bør have skabt stærke spændinger imellem intimitetens adskilte niveauer.

Længe var lægerne altså tilbageholdende med at fortage kropsundersøgelser ved indvortes sygdomme, og patienterne med at lade lægerne gøre det. Pulstagning forblev lægernes emblematiske berøring; den var let at udføre, gjorde hverken patienten eller lægen generte ved at kræve afklædning, og den efterlod et sort rum for fortolkning (Reiser (1978), 27). Den lette berøring mellem lægens finger og patientens bankende årer havde stærke rituelle dimensioner og tilhører den medicinske kropslæsnings klassikere. Det var forst fra 1800-tallets anden halvdel, at patienten skulle acceptere bogstavelig kropslig indtrængning fra lægens side - gennem vagina, tarm, svælg - som en nødvendig del af den diagnostiske procedure.

Her findes samtidig et helt centralt klasseaspekt. Kroppens integritet var de privilegeredes privilegium. For de øvre samfundslag var det medicinske møde en ligeværdig, klientbaseret relation snarere end hierarkisk. Berøringen af kroppen begrænsedes af samme regelsystem som gjaldt i øvrige sociale sammenhænge. For de lavere samfundslag gjaldt andre normer. I Sverige kunne man endnu under 1800-tallets første tiår ved mistanke om kønssygdom, tvinges til at defilere forbi lægens granskende blik med blottet køn. Den regulerede prostitution under 1800-tallets anden halvdel byggede ligeså på halvoffentlig inspektion af de blottede kroppe. På klinikken tilhørte så godt som alle patienterne de lavere samfundsklasser. Dette kom til at forskyde den medicinske relation, og dermed kropsberøringen, $\mathrm{i}$ autoritær og paternalistisk retning. Det kan med en vis ret hævdes, at udviklingen af den diagnostiske kropslæsning skete med underklassens krop som eksperimentfelt. På fast klokkeslæt hver dag indkaldes byens syge fattige til sygehuset, for "en efter en at blive kaldt ind og eksamineret af en studerende", skriver den svenske læge Magnus Huss som i 1830'erne befinder sig i Berlin, for at lære den nye metode (Nordström (1944-5), 162).

Men kampen om kroppen var ikke entydig. Det handlede ikke bare om hvis krop som blev undersøgt af bvem, men også om hvilken sygdomsopfattelse der gjorde kropsundersøgelsen relevant. Så længe sygdom tolkedes på humoralpatologisk manér, som ødelagte balanceforhold, eller på nervepatologisk, som mimiske spor på kroppens ydre, var aktiv kropsundersøgelse af begrænset værdi. Alternative sygdomslærere, for eksempel den mekaniske eller den kemiske, slog aldrig igennem i den medicinske praksis. Den idealistiske medicin betragtede kropsundersøgelsen som både unødvendig og uheldig. Sygdom var fra første hånd et moralsk spørgsmål. Israel Hwasser, professor i praktisk medicin i Uppsala og romantiker af den uhelbredelige slags, definerede medicinen som en højere kunst. Den var ikke en empirisk videnskab og endnu mindre et praktisk håndværk omkring 
berøring af kroppen eller fund i laboratorier og obduktionssale. At berøre kroppen var at berøre det besmittede, som skulle heles indefra.

\section{Klinikkens berøring}

Kropsundersøgelse i den moderne betydning, blev først meningsfuld på baggrund af et nyt patologisk-anatomisk sygdomssyn. Sygdom defineredes ikke længere som processer, der udspillede sig i åben samtale mellem krop og livsberetning, men som biologiske hændelser lokaliseret på bestemte steder i kroppen: Organ, væv og celler. Ved systematisk at observere sygelige forandringer i den levende krop og jævnføre dem med fund i den døde, kunne sygdom isoleres som egne selvstændige væsener.

Dette var kropsundersøgelsens teoretiske udgangspunkt og samtidig dens metode. Kun den sygdom som kunne ses, høres, føles, berøres, lugtes, smages og bogstaveligt talt betragtes $\mathrm{i}$ den åbne krop efter døden, havde gyldighed. Vejen til kundskab gik altså gennem lægens sanser.

Den kliniske metode etableredes i Frankrig efter århundredeskiftet 1800. Klinik (af græsk. Klina, seng) betyder undervisningssygehus. Som institution var den ikke et produkt af et moderne sygdomssyn (som det ind imellem fremstilles). Snarere tværtimod. Efter revolutionen, som indebar, at universiteterne og de gamle sygehuse var blevet lukket, gennemgik den franske medicin en radikal omorganisering. En ny medicinsk uddannelse blev oprettet, hovedsagligt placeret direkte ved de nye sygehuse. Her klassificeredes patienterne ikke efter hvad de berettede til lægen om deres symptomer, men efter de tegn som registreredes i deres kroppe. Journaler blev ført, både over den levende og den døde krop.

Processen beroede på teknikker, som kunne pejle kroppens indre: Lunger, hjerte, lever, mavesæk, livmoder. Som kunne trænge sig bagom hinder og vægge, ind i hulrum, gange og vindinger, opfange væsker, sammenvoksninger, hærdninger. Det er nu vi befinder os indenfor det navnkundige "medicinske blik", en metafor oprindeligt introduceret af Laennecs lærer Corvisart. Dette blik kendetegnes ved, at det flyttes fra kroppens ydre til kroppens indre. Den søgte programmatisk ind under huden, ind under kødets dække. Tegntydning var ikke længere bare at lase og tolke, men en serie af teknikker til projektivt seende (Foucault (2000), xx).

Dette indebar samtidig noget helt andet: At patienten hermed mistede sin selvfølgelige tolkningsret til sin egen sygdom. Hun omdefineredes fra oplevende subjekt til videnskabeligt objekt, fra at vare en krop til at have en krop.

Men jeg forlader netop dette perspektiv her. I stedet vil jeg fokusere på de kropslige aspekter af de nye teknikker. 
Det lyder som en truisme: Kropslæsningens kropslighed? Her findes i selve værket en ejendommelig stilhed. Samtidig med at den kliniske medicin betoner afhængigheden af lægens sanser, altså en mulighed for at tolke den syge krop gennem lægens egen, bliver samme læges krop hængende frit $\mathrm{i}$ luften. Subjektive sanser forvandles usynligt til objektive vidensinstrumenter. Denne usynlighed sætter præcist fingeren på kropsundersøgelsens uklare kundskabsteoretiske status. Den er kommet til at svæve mellem en sensualistisk, en semiotisk (tegntydende, diagnostisk) og en kommunikativ funktion.

Altså: Med hvilke sansebundne teknikker og med hvilket egen-kropsligt nærvær nærmede den 1800-tals moderne læge sig den syge krop? Det handler delvist om højest konkrete aspekter af det medicinske møde. Hvordan reguleres impulser knyttet til lægens subjektive krop, som eksempelvis erotisk attraktion eller forskellige former for afskyfølelser? Hvordan overvandt han ulysten overfor lus, skab og maddiker eller uviljen mod smuds? Dette synes at forudsætte snavsens rationalisering fra underklassemærke til bakteriologisk smittekilde inden for et større hygiejnisk program, som netop handler om modernitet. Den moderne krop, skriver historikeren Philipp Sarasin, blev vasket frem under et lag af lort, sved og hudaflejringer. Den måtte befries fra sørgerande, sammenfiltrethed, indtørret blod og sur svedlugt i skjulte hudfolder, den påtrængende lugt af sæd, sekret og hemmelig kønslighed (Sarasin (2001)).

I modernitetens forhold til kroppen findes ikke kun denne hygienisering, men også en slags bogstavelig fortrængning af kroppens irrationelle værende. Filosoffen Drew Leder har i fortsættelse af Foucault hævdet, at den dode krop udgør modellen for den vestlige verdens moderne medicin (Leder, 22). Først opskåren, kortlagt og desinficeret repræsenterer den sandheden om sig selv. Det handler ikke bare om den døde krop på obduktionsbordet eller det faktum at lægeuddannelsen indledes med mødet med en død krop og ikke en levende, men også om den "døde" sjælløse maskinkrop i cartesiansk betydning.

Allerede i undersøgelsessituationen slår dette kropsbillede igennem, hævder Leder provokativt. Patienten opfordres til at indtage en position som ligner ligets: Liggende, passiv, nøgen, stum. Hele ritualet reducerer den personlige identitet, løfter den oplevende krop ud af sin sammenhæng - til og med klæderne - og anonymiserer den på samme måde som i døden. Mens kroppen udforskes er patienten tavs. Lægen er den aktive opdagelsesrejsende, patienten hviler ventende på at blive afsøgt, forstået og forklaret. I overensstemmelse med maskinmodellen forventes hun kun at reagere på opfordring: Rejse sig, vende sig, løfte armen, gabe, hoste, tale.

Dette billede af kroppen, fortsætter Leder, har også styret den moderne medicins diagnostiske teknikker. Ligesom en automat, forventes patienten kun at svare på forud programmerede spørgsmål. De højteknologiske instrumenter 
fremstår som en slags dissektioner af den levende krop, uden at skære i dens ydre. Den optimale behandling er (jævnfør den samme maskinmodel) enten at erstatte skadede organer med kunstige, eller at kompensere for funktionsbortfald på syntetisk vis.

En sådan beskrivelse er unægtelig slagkraftig. Den bygger på trofast Foucaultlæsning, men er umiddelbart et kritisk udtryk for det fænomenologiske perspektiv, som Drew Leder selv bedriver, og som handler om den oplevende krop. Inden for rammerne af en kritisk medicinhistorie, udgår et sådant perspektiv næsten altid fra patientkroppen.

Mit eget blik er dobbelt og retter sig både mod patienten og lægen, som oplevende kropslige subjekter. Fra det udgangspunkt vil jeg undersøge fire sansebundne teknikker til diagnostisk kropslæsning: Perkussion (banke), auskultation (lytte), palpering (føle) samt touchering (berøre).

\section{At føle kroppen}

\section{1.banke}

I midten af 1700-tallet havde den østrigske læge Leopold Auenbrugger publiceret en beskeden lille bog, om at banke (perkussion, af percutio, banke, slå) mod brystbenet, som en teknik til at nærme sig kroppens indre. Han hævdede at sygelige hændelser i kroppen, men også sygdomsfremkaldende følelser, som stærk længsel, kunne aflyttes på de lyde, der trængte ud fra den syges bryst. Lægens øre kunne altså hore en sygdom på samme måde, som hans øje kunne se den gennem andre tegn på kroppen. Ved at berøre kroppen på en bestemt måde, kunne han kommunikere med dens indre sprog. Han kunne få kroppen til at tale.

Teknikken indebar, at man med fingrene bankede på patientens bryst, eller snarere, at man lagde den ene hånds fingre (den behandskede) mod huden og bankede på dem med den anden hånds fingre. Den fremkaldte lyd berettede om tilstanden af brysthulens organer (på samme måde som man kunne banke mod en tønde for at bedømme indholdet eller mod et metal for at bedømme tætheden). Augenbrugger nærede mistro til både patientfortællingen og den passive observation, og hævdede, at de lyde han selv - "gennem mine egne sansers vidnesbyrd" - kunne lokke frem fra kroppen, var en mere pålidelig kundskabsmetode. Allerede patientens kropskonstitution gav forskellige udslag: "De lyde som fremkommer, er hos magre lysere, hos kødfulde mere dæmpet og hos fede, på grund af fedtet, næsten ikke hørbare" (Augenbrugger (1762), 11). Høje resonanslyde tydede på, at brysthulen var "tom", altså ingen væskeansamling, ingen voksende svulst. En dump lyd tydede på et sygeligt indhold: Væske, inflammationer, udfyldninger, sammenvoksninger. 
Metoden indebar en strategisk forflytning af patientens centrale plads i diagnostikken og sygdommen, som hun selv oplevede den. Hendes egen brystfornemmelse kunne være illusioner, reflekser eller hypokondriske puds. Omvendt kunne brystets indre lyd afsløre, om hun bar på en sygdom som var skjult for hende selv. Et af Auenbruggers eksempler er nostalgi, militærlivets svære hjemve. Efter at være registreret gennem sine symptomer kunne den identificeres ved en særskilt dump lyd ved bankning og efter døden bekræftes på obduktionsbordet, $i$ form af bestemte synlige lungeforandringer.

Men banketeknikken var vanskelig, og spredtes først efter den var blevet introduceret $\mathrm{i}$ fransk klinisk medicin, nogle år inde i 1800-tallet. Den synes måske at være en rest af det forgangne jævnfør en antik metode; succussion eller rystning af patienten, for via eventuelle skvulpelyde at afgøre om væske fandtes $i$ brysthulen. (Denne rysteteknik syntes at have fået en renæssance ved 1800-tallets begyndelse, en meget kropsnær praktik med indslag af egentlig vold mod patientkroppen) (Theile (1855), 42-4).

Problemerne var flere. Hvor hårdt skulle man banke? Med hvilken fingerteknik? Hvilke dele af brystet skulle aflyttes? Fungerede teknikken gennem klædernes lag af tøj?

At formå at identificere og differentiere lyden krævede træning. Hvad var en normal brystlyd, og hvad var en afvigende eller sygelig? Hvad var en dump eller gennemtrængende lyd, en mørk og en lys, en bragende eller en stum? Hele kundskabsprocessen var kompliceret, en slags seende i flere trin, hvor hånd, øre og øje måtte samarbejde i en praktik, som byggede på øvelse og erfaring, men også på færdighed. (I selve værket er den en lysende illustration netop på forskellen mellem en erfarenhedskundskab og en færdighedskundskab). Lægen må først føle den syge krop med fingrene og lokalisere de bedste bankepunkter, derefter analysere bankelydens karakter, oversætte et høremønster til visuelle analogier - altså "se" ind i kroppen - og til sidst finde en verbal form for det han så. En særskilt besværlighed gjaldt sprogets begrænsninger; at overføre hørefornemmelsen til beskrivende ord på en måde, så andre kunne forstå dem. Visualisering udelukkende via sproget (altså uden billedillustrationer) er svært. Mens lægen måtte skrive om sine synsindtryk i ord, måtte de som læste det beskrevne gøre det modsatte, altså oversætte ord til synsindtryk. Kløfterne her er meget store. At tænke over øjet $i$ en medicinsk sammenhæng er ingen enkel relation mellem lægeblik og objekt, men fremhæver en række kundskabsteoretiske og metodologiske problemer. 


\section{Lytte}

Auskultation (af latin ausculto, lytte opmærksomt), at lytte med øret direkte til kroppen, var en anden teknik baseret på lægens sanser. Systematiseringen af de lyde, der trængte ud fra den syge krop - pludselig inden for rækkevidde, hørbare for yderverdenen - indebar en ny måde at lytte til kroppens tale på.

Teknikken var kendt fra gammel tid, men forbedredes og populariseredes fra og med 1820erne gennem en bestemt innovation, stetoskopet ("at se ind i brystet"). Historien er klassisk (og måske mytisk); den unge læge Laennec, oplært ved den nye pariserklinik, skal undersøge en ung kvindelig patient med hjertebesvær. Både forsøg på at banke og at føle med hånden over hjertetragten, for at opdage underliggende afvigelse, mislykkedes på grund af hendes fedme. At lægge øret direkte mod hendes bryst finder han upassende med tanke på hendes ungdom og kvindelige køn. I et lykkeligt indfald tager han nogle papirark fra natbordet, ruller dem til et rør, placerer rørets ene ende mod patientens bryst og den anden mod sit eget øre. Tydelige og distinkte hjerteslag kan høres.

Stetoskopet revolutionerede mulighederne for at kunne diagnosticere sygdomme i hjerte og lunger.

Det konverterede symptom til tegn. De symptomer som kunne observeres på kroppens yderside var begrænsede, primært hoste, åndenød, pibende lyde. Som tegn var de upålidelige, kunne variere ved en og samme sygdom eller te sig ens ved forskellige sygdomme. Kroppens indre tale var tydeligere. I en tung dokumentation aflagde Laennec regnskab for ikke bare hvad han hørte, men systematiserede lyden mod, hvad han forestillede sig at se på kroppens inderside og jævnførte det med, hvad han så i den døde krop ved obduktionsbordet. ${ }^{6}$

Sygdom kunne altså læses gennem lægens krop, forstærket med et lille rør af papir eller træ.

Men her fandtes ligesom med banketeknikken en række besværligheder. Den første gjaldt det at differentiere lyden, det krævede lang tids øvelse. Den anden gjaldt at oversætte høreindtrykkene til verbal, sproglig form. Myriader af lyd trængte ud af kroppen i venten på at blive navngivet. Sprogets begrænsninger var samtidigt plagsomt åbenbare. Et tredje problem var at systematisere lyden. Hvordan kunne f.eks. tuberkulosens lyd adskilles fra lungeinflammationens? Et fjerde gjaldt hvordan øret kunne forbindes med det anatomiske blik. Lytteteknikken krævede af lægen - som ved banketeknikken - at han skulle forvandle, det han hørte til et visuelt billede af kroppens indre, altså i virkeligheden at forvandle et hørende øre til et seende øje. Dette var på en måde det vanskeligste ved at udtrykke lytteteknikkens metode: "Vi ser direkte ind i kroppen!" Øret forvandles til et øje. 
Optimismen var stor over stetoskopets tænkbare anvendelsesområder; ikke bare lunger og hjerte kunne aflyttes, men også arterier, stemmebånd (f.eks. de døvstummes tale), tarme, led, frakturer (i form af knasen), hul i tænderne, galle- og urinsten, fosterlyd. Mistænkte simulanter kunne afsløres via kroppens indre og mere sande sprog. For at fastslå mistænkte, men fornægtede graviditeter kunne stetoskopet blive et redskab direkte i retsmedicinens tjeneste.

Men det lille trærør havde også en anden fortjeneste. Det placerede noget mellem patienten og lægen, et stykke materie, som forhindrede uønsket nærhed. At lægge øret direkte mod kroppen er ubekvemt både for lægen og patienten, påpegede Laennec, og desforuden upassende. Stetoskopet mildnede modviljen mod kropskontakt ved at repræsentere en både faktisk og symbolsk afstand. Det var, kunne man sige, det første instrument som videnskabeliggjorde det medicinske møde og tydeligt adskilte det fra andre intime møder. Måske er det netop derfor stetoskopet er blevet insigniet på lægens professionelle status, en talisman til at bære om halsen og samtidigt et bevis på hans videnskabelige ret til at se ind i en andens krop.

Den lyttende posering blev samtidigt en symbolsk gestaltning af den moderne læge, med sin krop tæt ind til den syges; jeg er mit eget instrument. På Theobald Chartrans ikonbillede af Laennec, fremstilles auskultationen som en rituel, næsten liturgisk akt. På den ene side den lyttendes blik, bortvendt - indadvendt i koncentration, kropssproget aktivt. På den anden side patientens lidende ansigt og afmagrede krop, som i venten på en dom eller frelse. Formåenhed til at kunne tolke kroppen - naturen kunne også forbindes med egenskaber, som blev tilskrevet kunstneren; lydhørhed, sensibilitet, intuition, fantasi, associationsrigdom, evnen til at skelne hårfint.

Men mange klagede over at teknikken var svær og beskrev frustrationen over, kun med besvær, at kunne skelne mellem hjertets og lungernes sprog ud fra den første "hvæsen". Netop at udskille uvedkomne lyde, blev for mange en anstødssten. En svensk læge beretter om , hvordan han længe havde forsøgt at lære sig teknikken, men blev irriteret af alle de uvedkomne lyde og usikkerheden om, hvilke aflytningspunkter på kroppen der var de bedste. Patienternes modvilje mod instrumentet var et andet problem. "Misfornøjet og nedslået smed jeg da en dag det instrument bort, som jeg syntes havde kostet mig så meget ubelønnet besvær, og lagde øret umiddelbart til patientens bryst. Hvad jeg tidligere kun med besvær og under stilhed på sygestuen havde kunnet høre, det hørte jeg nu let og tydeligt". "Laennec må sige hvad han vil...", skriver en anden svensk læge. "Det er dog en sandhed, at det ubevæbnede øre opfatter lydens fine nuanceringer lige så godt, og ofte bedre, end det med stetoskopet bevæbnede"? 
Det hele kunne også synes vanskeligt. Lyden kunne differentieres i det uendelige, endeløse klassificeringssystemer med underafdelinger og specialafdelinger skabes. I enhver 1800-tals vejledning om lyttekunsten finder man lange lister med fantasifulde navne på lyde; knurrende, gnistrende, brusende, blæsebælgslydende, filende og raspende, læderknirkende, spindende (Trier 1831). Forestillingen om at enhver afvigelse skulle repræsenteres af en individuel lyd (ligesom patonomikken gik ud fra at enhver sygdom skulle repræsenteres af et eget ansigtsudtryk) kunne virke lammende.

Den kvalitative terminologi var også svær at forene med ambitionen om, at identificere objektive tegn. Subjektiviteten fandtes både i ørets høren og i formåenheden til at differentiere fornemmelserne. Hvordan kunne en lydvæg af hvæsende, rallende eller gurglende lyde opløses i generelle kategorier? Her lurede et paradoks. Den lyttende kunst var umiddelbart bundet til lægens egen krop. Samtidig kom stetoskopet, mere end noget andet, til at skabe billedet af objektiv iagttagelse. Uden at distraheres af patientens egen beretning og oplevende krop, kunne lægen stille en diagnose under ledelse af et indre sprog, som kun han kunne høre, som kun han kunne tolke og som kun han kunne transformere til et anatomisk blik (Reiser (1978), 38.

\section{Fole}

Hørelsen var altså et sanseorgan, som kunne optrænes og tilpasses til det anatomiske blik. Det samme gjaldt følelsen.

Palpering (af palpo, føle, stryge) udgik, ligesom banke- og lytteteknikkerne, fra den patologiske anatomi. Med udgangspunkt i erfaringen fra obduktioner, handlede det om at finde ud af, hvordan et sygt organ gestaltede sig under kroppens ydre - en lever, milt eller nyre - ved at trykke eller stryge med hånden hen over huden. På samme måde som øret bliver et øje ved bankning eller lytning, bliver hånden et øje ved palpering. Den "ser" ved at føle kroppens indre i normale og unormale former, og med blikket rettet mod en anatomisk krop.

Denne søgende, følende hånd kunne bevæge sig over kroppens ydre eller forskellige dele af kroppen, som mandlerne, lymfekirtlerne, brystet med opmærksomheden rettet mod knuder, opsvulmninger og hårdheder. Den kunne identificere ømt væv, "hysteriske punkter" og forskellige smertezoner. Teknikken var for længst blevet vel afprøvet til at bedømme fostrets størrelse og stilling hos den gravide kvinde.

Palpering opfattedes som den mest enkle af de kropsundersøgende teknikker og mentes ikke at kræve nogen særlig dygtighed eller øvelse. Ifølge håndbøgerne kunne den udføres på tre forskellige måder. Den første bestod i, at man følte let med fingerspidserne på det underliggende organ. Den anden, at man pressede med indersiden af den ene hånds fingre eller håndflade mod 
den undersøgte del, mens man følte med den anden hånd på den modsatte side af kroppen. Den tredje måde var at trykke eller banke med fingerspidserne eller håndfladen, for at lokalisere for eksempel, fluktuationer (Theile (1855), 24-30). For bedre at kunne orientere sig angående kroppens indre, kunne teknikken til tider benytte sig af, at organernes konturer blev tegnet - som en medicinsk tatovering - med kul eller blækpenne på kroppen ydre.

Palperingsteknikken ansås godt nok som ukompliceret, men den var ømtålelig på grund af dens intimitet og dens association til den kærtegnende eller erotiske berøring. Hånden mod maven, bryst, lysken eller testikler i cirklende eller trykkende bevægelse, forudsætter en høj grad af professionel distance, for at holdes udenfor den subjektivt oplevede krop. Da en svensk 1800-talslæge beskrev hvordan en undersøgelse af en kvindes bryst burde udføres, strejfede beskrivelsen trods sin ydre videnskabelighed, ufrivilligt det pornografiske:

Ved undersøgelsen af brystet kan kvinden være oprejst; og klæderne bør være godt åbne. For at prøve om vorterne kan rejse sig behørigt, kan man gnide dem løst med fingerspidserne i cirkulære bevægelser. Vortebåndet og dets beskaffenhed åbenbares derved, at man forsøger at løfte og fremdrage vorten med fingrene. Vil man søge efter mælk; så lader man kvinden bøje sig lidt fremover, og stryger brystet sagte med hånden mod vorten ... samt foretager små hyppige klem med tommel- og pegefinger, lige bagved vorten (Cederschjöld (1836), 112).

Som kropshistorikeren Sander L. Gilman har vist, havde håndsberøringens metaforiske indhold forskudt sig, med 1600-tallets sekularisering, fra en åndelig og religiøs dimension til en kropslig og seksuel. Den hellige og helende berøring ("the holy touch") var blevet den syndige berøring. I 1700tallets billedverden symboliserede berøringen af den kvindelige krop både indledning til forførelse og til smitte (jf. Gilman). Huden var kroppens mest ladede zone for lyst, for smuds, for truende kontakt og for sygdomsstigma $\mathrm{i}$ form af sår, udslæt og bylder. For at accepteres som "ren" måtte berøringen samtidigt afsexualiseres, domesticeres og professionaliseres. En absolut grænse måtte fikseres mellem kroppen, som erotisk objekt for begær og som videnskabeligt objekt for analyse.

Palpering kan måske beskrives som den mest intime form for professionel berøring. Den kan ikke gemme sig bag et instrument og har ingen naturlige ydre grænse. Den beror på håndens sensibilitet og en slags dialogisk kontakt med den krop, som berøres. 1800-tallets håndbøger regulerede også situationer med hensyn til intimitetsaspektet. Hvorvidt det af diskretions- 
og anstændighedshensyn var umuligt at palpere brystkassen, hvorvidt den følende hånd kunne flyttes til f.eks. nøglebensregionen, for derfra nænsomt at nærme sig kroppen. Når det blev påpeget, at patientens skamfølelse ikke måtte vækkes, gjaldt det uden tvivl en patientkrop fra de højere sociale klasser.

\section{Berore}

Den gynækologiske berøring, kaldt touchering, spiller en afvigende rolle i denne sammenhæng. Den udelades næsten altid i kropsundersøgelsens historie, en bemærkelsesværdig og synlig udeladelse. Den gynækologiske undersøgelse sprænger også mønstret for, hvilken grad af intimitet, der var mulig i det medicinske møde.

Medicinens berøring af det kvindelige underliv, var givetvist kontroversielt af en række moralske grunde. Men den var også den første diagnostiske teknik, som indebar at videnskabens hånd, fra midten af 1800tallet kompletteret med vaginalspejl (speculum), i undersøgende øjemed gik ind i den levende krop. Undersøgelsen var omgærdet med en række forskrifter om de passende arrangementer. Her findes der interessante nationale forskelle i relation til religion, konvention og tradition. Det gjaldt blandt andet den anbefalede undersøgelsesstilling for kvinden: Stående, siddende, siddende i hug, liggende på ryggen eller i sideleje, foroverbøjet eller stående på alle fire (á la vache). Mens firfodspositionen var almindelig i katolske lande, var den tabuiseret i protestantiske. Dette gjaldt også den kliniske indramning: Fra klodsede undersøgelsesborde $\mathrm{i}$ afskallede miljøer, til sofaer, chaiselonger og kanapeer i hjemlige, private rum. Undertiden fremmanedes meget intime undersøgelsessituationer. Den svenske kvindelæge Pehr Gustaf Cederschjöld anbefalede den følgende position som den bedste:

Man lader kvinden stige op, f.eks. på en sofa, og sætte sig på hælene. Undertiden kan det være nyttigt at hun læner sig bagud, så underlivet kommer i en halvliggende stilling (Cederschjöld (1836), 112).

Omgivelserne skal være rolige. Ingen anden person bør være til stede, undtagelsesvis en nær kvindelig slægtning. Den undersøgende læge sidder ned eller ligger på knæ. Hans krops- og ansigtsudtryk skal være behersket. Under undersøgelsen bør hans øjne være lukkede eller bortvendt. "Man skal ikke såre kvindens anstændighedsfølelse, tag derfor så sjældent som muligt øjnene til hjælp, blotlæg ingen del af kroppen unødvendigt, fjern alle vidner og vær diskret", skriver en tysk læge i sine forskrifter. Det ydre og det indre køn bør først toucheres under tøjet (von Droriep (1806), 314). Cederschjöld anbefalede dog at undersøgelse med hånden blev kombineret med besigtigelse 
(inspektion), altså med øjet. Termen besigtigelse associerer til et distanceret og objektivt blik (til forskel fra den deltagende observations). Begrebet har også i begyndelsen været anvendt i kombination med en kontrolfunktion til undersøgelse af den smittede krop i almindelighed og den kønssmittede $\mathrm{i}$ særdeleshed. Valget af term var for den gynækologiske situation helt sikkert tilsigtet; sammenblandingen af det subjektive og det objektive blik måtte for enhver pris undgås.

Fra patienternes side var modstanden mod den gynækologiske undersøgelse stor, og den måtte have været svær at håndtere for huslægen. De fleste af 1800-tallets gynækologer diskuterer lægernes svaghed for $\mathrm{i}$ for høj grad at lytte til patientens ønsker og udelade den nødvendige undersøgelse. Den må gennemføres selv om patienten viser ulyst, uro eller ængstelighed. "Nervøs snøften og gråd lader sig ofte med fordel udnyttes", skriver en tysk gynækolog. "Gennem den stødvise udånding, som da indfinder sig, kan hånden trænge dybt ind, uden at møde modstand" (Hegar \& Klatnbach (1886), 39). Det gjaldt om at få overblik over så store dele af underlivet som muligt, men uden at berøre klitoris og "andre ømfindtlige dele".

Livmodermassagen var en gynækologisk teknik med meget stort kropsligt nærvær - en metode hvor man ved hjælp af at stryge, massere og "trække", korrigerer livmoderens stilling eller form (Johannisson (1994), 214-220). For undersøgelsen anbefaledes følgende: Siddende foran patienten med den ene arm om hendes liv og hovedet mod hendes mave gennemfører lægen en indre undersøgelse med den frie hånds fingre. Ved behandling placeredes patienten i rygleje, lægen tæt ind til, patientens ene fod låst under hans lår og derefter bimanuel teknik med den ene hånd mod bugen og den anden i vagina. Billedillustrationer viser intime scener med massør og den halvt afklædte patient med bortvendte blikke, fordybet i en fysisk, ubestrideligt seksuelt ladet situation. En læge hævdede at man med genitale manipulationer også kunne forebygge spændinger og dæmpe smerte. De fleste diskuterede åbent risikoen for seksuel stimulans, men konstaterede at den ikke var større end ved ordinære gynækologiske undersøgelser.

\section{Den fysiske diagnostiks nye krop}

De nye diagnostiske teknikker var dobbeltbundne: Samtidigt revolutionerende og svært håndterlige, lokkende $\mathrm{og}$ frastødende. De indebar en redefinering af lægens professionelle identitet fra teoretiker til praktiker, fra observatør til aktør. Det medicinske møde omfokuseredes fra tale til berøring. Fra "skrivebordsmedicin" og behørig afstand tvinges lægen frem mod den syge krop, til at nærme sig den andens kropslighed og til at anvende sin egen. 
Teknikkerne spredes over Europa med en vis indledende tøven. Nogle steder var man afventende, andre steder var man direkte fjendtlig. Ved universitetssygehuset i Wien var audition i $1830^{\prime}$ erne udtrykkeligt forbudt og i Uppsala hævdede professoren i praktisk medicin, at kropslæsningens eneste formål var "at forudsige hvad man ville finde i kadaveret ved obduktion" (Nordström (1944-5), 162). Den særligt dygtige diagnostiker havnede let i den ene af to bokse: enten som en charlatan, der var alt for tæt på patienterne eller som videnskabens kyniker, der var mere interesseret $i$ den døde end i den levende krop, besat af at få sit diagnostiske skarpsind bekræftet ved obduktionsbordet. Nogle kritikere definerede også de nye metoder som inhumane; at

tvinge Patienten til dybe og plagsomme indåndinger for at man med Stetoskopet i sjældne tilfælde kan høre crepitation/ knaster/ ar, er mildt sagt urimeligt. ${ }^{8}$

Der rådede usikkerhed om kropsundersøgelsens sociale og moralske regelsystem. Kunne den fortages på personer af højere rang? Kunne den afkræves mod patientens vilje? Hvordan skulle den tilpasses til ordinær etikette og konvention?

Et særligt problem var berøringen af patientens nøgne hud. Var den acceptabel? Var det muligt for lægen at lægge hovedet mod patientens bryst? Laennecs beretning illustrerede flere moralske og kønspolitiske hindringer. Problemet er stadigt tilbagevendende, gennem hele 1800-tallet. Forskellige forskrifter viser også, at den nøgne hud er kropsundersøgelsens mest ladede dimension; generelt anbefales det at kroppen blottes så lidt som muligt. Stedet, hvor bankningen eller lytningen fortages, bør være dxkket af patientens underklæder, en tynd "elastisk jakke" eller eventuelt et håndklæde. Så snart en bestemt del af kroppen er undersøgt må den tildækkes inden det næste areal frilægges. Lægen kan med fordel bære handsker.

Men spørgsmålet om den afdækkede hud splittede. En læge opfordrede sine kolleger til at undersøge kroppen

uden ethvert stykke dækkede tøj, som kan forstyrre den nødvendige eksamination - altid med hånden og helst med øjet... lægen må sætte sig ud over patientens modvilje lige meget hvor stor den end er eller hvor naturlig eller anstændig vi opfatter den. ${ }^{9}$

Man anførte også tekniske grunde for afklædningen; den mellemliggende tøjhinde skabte raslelyde og mindskede høreindtrykkets stringens. Ved 
bankning kunne man anbringe en lille skive af glas eller elfenben (plessimeter) mod kroppen "som gør lyden tydeligere end hvis bankningen fortages på "integumenterne" (hudfladen).

Ved lytning uden stetoskop, altså med øret direkte mod bryst eller ryg, placerede lægen almindeligvis et håndklæde mellem sin egen og patientens krop. Håndklædet anvendtes altid når hovedet lagdes mod patientens bug for at aflytte tarmlyde. Håndklædets etik reguleredes af lægen. Klædets formål var på den ene side at beskytte ham mod stødende intimitet, på den anden side at beskytte patienten mod blusel og skamfølelse.

Men også træstetoskopet blev opfattet som upraktisk. Det var tungt og klodset og dets korte længde tvang lægen til at bøje sig ned (hvilket blev anset for at være ubekvemt, specielt hvis han var fedladen) og patienten til at vende og dreje sig. Det drev fremdeles lægens krop meget nær patientens. For den kvindelige patient var det ømfindtligt af anstændighedsgrunde, for overklassepatienten af høflighedshensyn, for de sensible og ængstelige af ømtålelighedsgrunde. For underklassepatientens krop gjaldt andre hindringer; smitterisikoen, afsmagen for den urene krop, for lugt, smuds og sved.

Omkring midten af 1800-tallet, lanceredes stetoskopet i nye forlængede modeller og i 1870`erne i sin moderne form, som et kort rør med to smidige gummislanger til at placere direkte i lægens ører. Dette betød at afstanden mellem lægens og patientens krop øgedes. Denne øgede afstand var meget betydningsfuld. Intimiteten blev brudt på to måder. Lægen slap for uønsket nærhed til patientkroppen. Samtidig forvirrede hans eget kropslige nærvær ikke - åndedræt, duft og kropsvarme, kildrende skæg eller hår - billedet af et ritual med en bestemt hierarkisk orden.

Afstanden mellem lægens og patientens krop havde altså både praktiske og symbolske funktioner. Den moderne medicins kropsintimitet er strengt reguleret. Samtidig er mødet i enerum blevet en forudsætning for den diagnostiske kropsberøring (den gynækologiske undersøgelse er en undtagelse). Forestillingen om at det medicinske møde hører til privatsfæren - altså bør udspilles mellem to individer beskyttede fra andres blikke og indblanding - er en nyhed i 1800-tallets medicinske praksis og en del af dens videnskabeliggørelse. Tidligere defineredes dette møde, som en større social akt. Den offentlige dimension var en del af medicinens troværdighed; familie, slægtninge, venner, naboer og andet publikum deltog i behandlingsrummet som vidner, kontrollanter, stedfæstere, medlidere, kritikere.

Relationen er kompliceret mellem den moderne medicins "lukkede døre og gardiner" og de intime handlinger, der udspillede sig bag dem. Ud over skrevne koder forudsætter situationen en tavs kontrakt mellem lægen og patienten, bygget på gensidig accept af videnskabens objektive blik. Den forudsætter også en bestemt paternalistisk rollefordeling omkring to 
hovedprincipper; adskillelse og overordning/underordning. Det medicinske mødes sociale forordning sammenfalder dermed med kønsforordningen.

Det var de medicinske videnskabers voksende status fra og med 1800tallets anden halvdel og lægens fortolkningsforrang i forhold til den syge krop, der gjorde det muligt at forvandle denne til et objektivt "afmystificeret" ydre. Også af sin egen krævede lægen en neutraliseret krop. Den måtte udstråle ro, autoritet og tilbageholdenhed. Ansigtsmimikken måtte aldrig røbe en fatal prognose, kropssproget måtte være behersket. Det erotiske blik, som indtil nu havde kunnet nævnes i håndbøger og etiske regelsystemer, forsvinder helt ud af medicinens selvrefleksion. I lægeuddannelses tavse praktikker indgik indlæringen i det, som er blevet kaldt objektivitetsmasken eller "den objektive velviljes ansigt".

Et objektiviseret syn på kroppen blev også afkrævet patienten. I den videnskabelige demonstrations navn kunne den nøgne patientkrop ureflekteret eksponeres for offentlighed, kolleger eller studenter. Videnskaben afgjorde intimitetens og integritetens grænser. Ulyst, blusel og skamfølelse usynliggjordes eller affejedes som irrelevante. Eksemplerne på, hvordan medicinens blik kunne fjerne sig meget langt fra det oplevende subjekt er mange, som her i en ung svensk læges rapport fra en amerikansk gynækologisk klinik i 1800-tallet:

eksamination og behandling gik som den skulle aldeles som hos os, forhænget blev trukket for og det vulva tilhørende menneske levnede plads for en ny vulva, formodentlig var også den efterfulgt af en hel kvinde. ${ }^{10}$

Michel Foucault har hævdet, at det ikke var skam og moral, der gjorde kropsundersøgelsen følende, men at denne skam først opstår med videnskabens blik. Altså, så længe relationen ikke var hierarkisk, uden jævnbyrdighed; ingen skam. Udtalelsen er, som ofte hos Foucault, svagt empirisk forankret. Kropsundersøgelsen var næppe aktuel før 1800, og skamhypotesen er derfor vanskelig at efterprøve.

Imod billedet af videnskabens kølige blik står en rig dokumentation, som beretter om meget kropsnære relationer mellem patient og læge, specielt gælder det nervelægen, kvindelægen og efterhånden den psykoanalytisk orienterede læge. Kvindelægen Pehr Gustaf Cederschjölds veldokumenterede behandlingsteknikker fra 1830`erne er forundringsværdige: touchering gennem kvindekroppens forskellige åbninger, massage af bug og underliv, ufravigeligt en kønsligt ladet symbiose. Nervelægerne i 1800-tallets anden halvdel nærmede sig sine kvindelige patienter på lignende måde. Charcot på sin klinik presser og trykker på hysterikerens krop; ørefigner, slag og fysisk kamp med 
krammende eller faldende kroppe indgår i en ejendommelig kvindemedicinsk diskurs. Kvindekroppen liggende på en chaiselong bag lukkede gardiner i det private rum med luften tung af dufte, signalerer et tvetydigt kønsligt nærvær. Freud behandler Emmy von N med daglige bade og massage. Og Groddeck undersøger sine patienter ved at lægge sit hoved mod deres mave og lugte til deres køn. Selvom den kropslige intimitet givetvis varierede, opfattedes århundredskiftets fremgangsrige patientlæger alle beroringer som en central del af lægens professionelle rekvisit.

At være dygtig diagnostiker blev da også, under 1800-tallets sidste årtier, en af medicinens mest prestigefulde roller. At være i stand til at stille diagnoser, symboliserede lægens kunnen, så længe evnen til at helbrede var begrænset. Diagnosen besvarede usikkerheden, gav bekræftelse på sygdomsoplevelsen, lagde en strategi for behandling og gav $i$ bedste fald et håb om helbredelse. Den konkrete diagnostiske procedure indeholdt terapeutiske, rituelle indslag, som kan sammenlignes med liturgiens; fra ihukommelse (skrifte), kropsundersøgelse (bekendelse), prognose (prædiken), til recept (nadver). Den havde yderligere to vigtige funktioner; den krævede godt med tid ved patienten og den indebar en dialogisk, kropsligt nærvær.

Kropslæsning kunne også fremstå som en højt sofistikeret kundskabspraktik. "At lede efter ethvert tegn hos patienten, lige meget hvor trivielt, var en betydning jeg ikke forstod ... ansigtsudtrykket, kindernes og læbernes farve, adamsæblets bevægelse, forandringer i pulsens karakter og rytme, gåsehud, afvigelser i hjerteslaget”, sådan beskriver en læge den diagnostiske kunst ved århundredeskiftet til 1900. At lære, ikke bare at registrere, men at tolke symptomer kræver lang træning, sansernes lydhørhed og intuition, detektivens sporsans - en stille færdighed bundet til lægens egen krop (Mackenzie (1920), 84.

\section{Den moderne medicins allierede praktikker}

De nye diagnostikere hævdede, at kropsundersøgelsen overgik diagnostikkens traditionelle metoder, dvs. patientberetning og observation af sygdommens gestaltning på kroppens ydre. De byggede på en mere eksakt anatomisk-klinisk sygdomsforståelse. De byggede også på mere eksakte data end patientens fornemmelser, nemlig lægens egne sanseindtryk og formåen til at overføre det øret hørte og hånden følte, $\mathrm{i}$ visuelle, verbale og tolkende former.

Stetoskopet spillede en nøglerolle i den nye diagnostiks praktikker. Det gjorde både vidnesteknikken og den narrative teknik underordnede. Det er blevet påpeget, at patientens stemme er blevet tavs, både symbolsk og bogstaveligt, da lytning krævede absolut stilhed. Kroppens indre talte et mere eksakt sprog 
end den talende mund. Samtidig isoleredes lægen i en verden af indre lyde og billeder, utilgængelig for patienten. Den oplevede sygdom kom til at betragtes som mindre relevant, og ind imellem endda med mistro (denne mistroende ideologi er en anderledes måde at nærme sig den moderne adskillelse af tegn og symptom på).

De nye teknikker medførte også at blikket styredes mod en bestemt type af sygdomstegn; de som kunne høres, føles, og bekræftes efter døden i obduktionssalen. Den hørbare lyds status af objektiv sansning hvilede helt på den bevisbare sammenhæng mellem lydens egenskab og sporene i den åbne krop.

Men øret er et vanskeligt sanseorgan. Formåenhed til at differentiere lyde varierede med graden af træning og perceptuel sensibilitet og dermed med lægens subjektive krop. Allerede samtidens kritikere påpegede, at øjet er langt mere kraftfuld end øret til at identificere patologiske spor i kroppen og sammenligne dem med rimelig objektivitet. Det er godt at lægen anvender alle sine sanser, kommenterede en svensk læge angående den nye diagnostik,

men den som bedst kan undværes af dem, tror jeg er hørelsen ... de vigtigste er syn og følelsen. ${ }^{11}$

Mens øret ikke effektivt kan afskærme uvedkommende lyde - problemet med at gøre det ydre rum stille nok var tilbagevendende - kan øjet fokusere, afskære, koncentrere. Metaforen for kundskab har i den vestlige verden altid været at se. Blikket antages, i højere grad end de øvrige sanseorganer, at bære på objektivitet. ${ }^{12}$

Øjet, synet, at se var altså den højest rangerende af sanserne. Det som ikke kunne ses med det blotte øje, måtte gøres tilgængeligt for øjet gennem forskellige visualiseringsteknikker. Beskrivelsen af stetoskopet, som et instrument for det at se, afslørede en særlig lægedrøm: at se ind i den levende krop, på samme måde som ellers kun var mulig i den døde (Reiser (1978), 61). Vivisektion (eksperimenter på den levende krop) var et mere brutalt aspekt af denne drøm, et andet, at konstruere instrumenter som kunne fungere som et forlænget, forstærket eller et ekstra øje.

Dette krævede ikke bare en funktionel "indtrængende" form, men også at mørket inden i kroppen måtte besejres. Lægeøjet måtte forbindes med et reflekterende lys, så hulrummet - øje, øre, hals, livmoder, mavesæk, tarm, urinblære - han kiggede ind i blev oplyst, på samme måde som en mørk grotte. Omkring midten af 1800-tallet skabtes en række af sådanne instrumenter med hvilke man kunne se dybt: Oftalmoskopet (øjet), laryngoskopet (struben), gastroskopet (mavesækken), laparoskopet (lysken). 
At se konkurrerede nu med det at lytte, som lægens sansebundne teknik til at nå ind i kroppens indre med. De lyttende teknikker tvang ham til at gå en omvej via abstrakt visualisering. De nye instrumenter tillod ham nu, bogstaveligt talt, at udforske kroppens dyb med et tredimensionelt blik, uden at penetrere dens flade. Lyd syntes også, ligesom lugte, smag og føleindtryk, at være mindre substantielle end det øjet faktisk så.

Fotografiet - kameraøjet - som begyndte at blive anvendt til medicinsk dokumentation omkring midten af 1800-tallet, vakte håbet om at kunne fiksere det patologiske tegn i absolut visuel form. Kameraets "mekaniske objektivitet" fjernede tilbageværende spor af subjektivitet mellem betragteren og det betragtede. ${ }^{13}$ Røntgenbilledet fremstod, i $1890 ` e r n e$, næsten usandsynligt virkeliggørende; at kunne se lige igennem kroppens skal, ind gennem muskler, hinder og organer og ind til det afskrabede skelet. Røntgenstrålingen opfattedes som et samtidigt magisk og materialiseret øje ind i kroppens inderste dyb og hemmeligheder. For første gang kunne det levende foster iagttages inden i kroppen, svævende med bøjet nakke i sit eget rum.. Også patienten kunne koble mærkelige kropslige drømme med dette dybdesyn. Hånden kunne fotograferes overdækket med juveler - et slags kroppens teater, som spillede på temaer som indre aristokratisk skønhed, rigdommens imaginære materialitet eller kroppens forgængelighed. Forelskelse kunne gestaltes med et røntgenbillede af de elskendes sammenflettede hænder (Reiser (1978), 61). I Thomas Manns Trolddomsbjerget (1924), bar hovedpersonen Hans Castorp et røntgenbillede af den elskedes lunger, tæt til hjertet. Intet diagnostisk blik har skabt en lignende videnskabelig og offentlig begejstring. Den udviskede skillelinjen mellem kroppens yderside og inderside; de var begge mulige at afbillede visuelt.

Røntgenblikket udfordrede ikke kun hørelsen, men også anvendelsen af berøringen i diagnostikken. Et benbrud var tidligere blevet diagnosticeret ved manuel undersøgelse og inspektion af hævelser og benstumper. Røntgen gjorde dette overflødigt eller underordnet. Fremmede genstande i kroppen, som man tidligere havde søgt efter med fingre og instrumenter, kunne nu pludselig lokaliseres med røntgenbilledets præcision. Mens instrumenterne kun kunne betjenes af en ad gangen, kunne røntgenbillederne analyseres kollektivt. Til forskel fra instrumenterne, krævede røntgendiagnostikken ikke engang patientens tilstedeværelse.

Men også andre teknikker bidrog til at øge afstanden mellem medicinen og den oplevende krop. Et helt repertoire af teknikker til måling af temperatur, blodtryk, blodsænkning og forbrænding, udvikledes fra 1870`erne og frem. Selv om der tidligere var foretaget målinger af puls og kropsvarme, var måleværdierne ikke blevet kvantificeret. Nu fikseredes pulsens betydning for kroppens status, ved helt enkelt at udregne den og angive normalværdien. 
På samme måde fikseredes grænseværdien for kropstemperatur i relation til døgnrytme, nedkøling eller infektionstilstande. Angående anbringelsen af termometrets placering på kroppen udvikledes forskellige anbefalinger (sikkert en analyse værd, i relation til kultur og konvention): fra den uskyldige navle og kyske armhule til den obscene analåbning og tvetydige mund.

1900-tallets begyndelse kendetegnes af et meget stort repertoire af medicinske måleinstrumenter. Kroppen fremstod mere og mere som en maskinkrop, hvis kraft, aktivitet og potens kunne beregnes; hjerteslag og tarmfunktion, motorik og reflekser, hudfølsomhed og stesstålelighed. At kvantificere og lave kurver og tabeller over temperatur, blodplader, hjertets rytme, nyrens eller lungernes kapacitet, intensiverede forestillingen om det visuelle medies mekaniske objektivitet. Den syge krop gestaltedes i en tegnform, som kunne tolkes generelt og entydigt. I stedet for at høres, føles, lugtes og berøres kunne patienten projiceres op på en skærm, aftegnes i cifre eller synliggøres under mikroskopet.

Øjet, synssansen, repræsenterede sandheden om kroppen.

\section{Den fraværende krop}

Men patienten selv syntes at rykke længere bagud i billedet.

I løbet af 1800-tallet var en ældre form for medicinsk møde blevet erstattet af kropsundersøgelsen og den systematisk, sansebaserede søgen efter spor og korrelationer. Men netop med denne nye kropslæsning begyndte, mærkeligt nok, den separation mellem det syge individ og hendes sygdom, som Foucault beskriver, både mellem objektive tegn og subjektive symptomer. Således opgav man f.eks. lytteteknikkerne, hvis fordel var at lægen blev uberoende på patienten selv, som "jo hverken kan simulere eller skjule lydene, forstærke eller formindske dem" (Reiser (1978), 31). Jagten på den objektive sandhed om kroppen drev efterhånden lægen til at erstatte sine egne sanser med instrumenter og kvantitativ analyse, men også med eksperimentel fysiologi og laboratorieteknikker; at studere sygdom gennem kroppens mikrostrukturer.

Suget mod laboratoriet -ikke klinikken - som nøgleplads for medicinen, var allerede tydeligt omkring århundredeskiftet 1900. Kritikken af denne udvikling har været en evig følgesvend, men er succesfuldt blevet fortrængt fra medicinens fremskridtshistorie. Omkring første verdenskrig, advarede James Mackenzie i The future of medicine om, at evnen til at tolke den levende patient var på vej til at blive udrangeret. Samme kritik formulerede Karl Jaspers i Der Artz im technischen Zeitalter og her i vor egen samtid er den blevet gentaget af bl.a. James le Fanu i The rise and fall of modern medicine (1999). 
Altså: klinikkens fødsel indebar at mødet mellem patient og læge som sindsbillede for medicinen, blev erstattet af et nyt billede; videnskabsmanden som undersøger et objekt. Det betød en afgørende separation. Den som bar sygdommen befandt sig i én verden, han som skulle fortolke den i en anden. Dette er ikke bare problematisk fordi patienten næppe kan reduceres til et objekt, men fordi den medicinske praksis forbliver et møde mellem mennesker og kroppe (Svenaeus (1999), 56).

Drew Leder har nedlagt et hermeneutisk-semiotisk perspektiv på medicinens praksis. Ifølge ham læser lægen kroppen som en serie tekster. Det syge individ er den primære tekst, som tolkes gennem fire hjælpetekster; den oplevelsesmæssige (patientens subjektive fornemmelser), den narrative (patientens beretning), den fysiske (kropsundersøgelse) og den instrumentelle (Leder (1990). Hovedpointen med Leders perspektiv er, at det vil opløse dikotomien mellem to adskilte kroppe. Lægen læser sygdommens tegn gennem forståelsesmodeller, der er bundne til bans egen levende krop; syn, hørelse, følelse og lugt. Det er en interaktiv læsning. Ved at sammenlænke sit øje eller øre med patientkroppen, hengiver han sig til en sansebunden dialog. ${ }^{14}$

Men spørgsmålet er, på hvilket niveau kroppens sprog skal læses og tolkes. Endvidere om sprog- og tekstmetaforen overhovedet er relevant. At betragte kroppen som en skreven tekst kan diskuteres, dagens diskussion fokuserer snarere på kroppens evne til at omskrive sig gennem somatisering og selvudsultning, træning og piercing, transseksualisme, plastikkirurgi og reservedelsteknologi. Sprog defineret som tegnsystem, findes i en række dimensioner - fra mimik og gestik til synlige symptomer og tegn og videre til dybtliggende koder for de biologiske (neurologiske, immunologiske, genetiske) processer, såvel som for individernes historisk og kulturelt bundne krop. Indesluttet $i$ teksten om sig selv risikerer patienten atter at blive tabt af syne.

En af de få læger, der har problematiseret den diagnostiske kropslæsning, er Richard J. Baron. ${ }^{15}$ Han fremstiller diagnosen som en slags kamp mod kroppen. Modernitetens medicinske blik har handlet om at gennembore og gennemlyse kroppen ligesom i 1800-tallets anatomiske model. I den forståelse er den levende krop en hindring, idet den vægrer sig ved at være en gennemskinnelig skærm, hvorpå sygdommens silhuet projiceres. Lægens opgave bliver netop at gøre kroppen gennemsigtig ved hjælp af en serie læseteknikker. Men der findes ingen neutral, generel krop at læse: Hjertelyde kan være svære at differentiere, en overvægtig krop eller en arret lyske kan være svære at palpere, en kildret, spændt, bange eller smerteplaget patient kan være hindringer for kroppens tale. Netop denne subjektivitet er blevet erstattet af den moderne teknologis ukropslige blik. Ultralyd ser smertefrit ind i kroppen, ct-scanneren arbejder lydløst, PET-kameraet føles ikke. 


\section{Sammenfatning}

Ifølge det medicinske blik, som introduceredes ved 1800-tallets begyndelse, kunne sygdom kun klassificeres på basis af organforandringer i kroppen som kunne ses, høres, føles og bekræftes efter døden i den åbnede krop, altså på patienten, defineret som biologisk krop. Disse forandringer identificeredes ved hjælp af observationer, som udgik fra lægens sanser; syn, hørelse, følelse, lugt og smag. Medicinen blev kropslig, patientens krop mod lægens.

For at dette skulle blive muligt, måtte kroppen forvandles, disciplineres, objektiviseres. Men processen, at forvandle både patientens og lægens krop, var besværlig. En række instrumenter kom imellem dem - instrumenter som skærpede og forfinede den diagnostiske formåen, men som samtidigt distancerede patientens krop fra lægens. Objektivitet forudsætter distance. Netop derfor kom patientnære, håndspålæggende læger som Charcot og Freud, Groddeck og Axel Munthe til at blive betragtet med mistænksomhed af deres kolleger.

Det kan hævdes at de manuelle teknikker synes at være tilbage hvor de engang startede; som simple håndelag, dunkle sanseindtryk, tvetydig berøring uden evne til at afsløre sygdommens egentlige væsen. Instrumentelle og tekniske metoder trængte sig dybere ind i sandheden om kroppen. Strengt taget behøvedes det kropslige møde mellem læge og patient ikke længere. Konsultationen kunne ske ved at et antal prøver af patientkroppen analyseredes på laboratoriet og blev overladt til lægerne at kommentere.

Scenariet er tilspidset, men ganske rimeligt. I 1970'ernes politiske kritik af et autoritært, naturvidenskabeligt fikseret system kom det også til at inkarnere en skrækvision af en mere og mere afhumaniseret medicin, en medicin uden nærværende kroppe. ${ }^{16}$

Spøgsmålet er snarere, hvorfor den moderne medicin ikke er havnet her. Hvor langt kan man gå i udbytningen af menneskets nærvær med instrumenter og teknologi? Og, hvor langt kan man strække billedet af mennesket, som "ren" krop, forløst fra sin levende sammenhæng? Maskinkroppen har været standard i billedet af den moderne biomedicin. Den er blevet kritiseret intensivt for ikke at modsvare menneskelig erfaring, splitte jeget i krop og sjæl og at den lod sig misbruge politisk, økonomisk og ideologisk. Fænomenologer, antropologer, historikere, medicinske filosoffer og feminister har tematiseret kroppen i radikalt nye spor.

Men det er næppe som med maskinkroppen, der synes gradvist mindre nærværende i den postmoderne medicin. I stedet rettes blikket mod en ny krop, som kaldes systemkroppen. Dette indebærer at blikket flyttes fra reservedelsideologi (at erstatte syge dele med nye) til biocybernetik (at regulere sygdom ved at kommunikere med og styre eller efterligne kroppens egne koder). Lægen 
skifter rolle fra mekaniker til programmør (Borck (1996). Det betyder også, at medicinens øje ikke bare rettes mod kroppens mikrostrukturer, men mod dens makrostrukturer - store og dybtliggende dialogiske sammenhænge. Den talende krop står i fokus igen.

Oversat fra svensk af Allan Olesen

\section{Noter}

${ }^{1}$ Om Groddeck se Grothjan (1945), 32: 9-24; jvf Robertson Davies (1998), 98-99.

${ }^{2}$ Denne skelnen findes f.eks. i Nationalencyclopedin (1995) : "Symptom ( af græsk symtoma $=$ hændelse, ulykke ) er subjektive til forskel fra sygdomstegn". "Sygdomstegn = sygdomsytringer som opdages af læger ved undersøgelse af en syg person".

${ }^{3}$ Jvf til det følgende Stanley J. Reiser (1978).

${ }^{4}$ Denne beskrivelse findes oprindeligt i Hippokrates Prognostikon, men forekommer mange steder i 1700-talslitteraturen. Om fysiognomikken se Claudia Schmölders (1995).

${ }^{5}$ Se f.eks. Roy Porter, "The rise of physical examination", i W.F.Bynum \& Roy Porter, Medicine and the five senses (Cambridge: Cambridge University Press 1989) ; Hans Peter Duerr, Nakenhet och skam: Myten om civilisationsprocessen, I (Stockholm/Stehag: Symposion 1994).

${ }^{6}$ R.T.H. Laennec (1829). Om Laennec se Duffin, To see with better eye.

${ }^{7}$ Her efter Nordström, 218-19.

${ }^{8}$ Per Christian Westring, brev til Svenska Läkaresällskapet 1823, her efter Nordström, 212.

${ }^{9}$ John Forbes ` forord i R.T.H. Laennec, A treatise on disease of the chest, (1821), xvi.

${ }^{10}$ Hugo Toll, brev til Johan Rodling $21 / 7$ 1888, Uppsala Universitetsbibliotek.

${ }^{11}$ Westring, her efter Nordström, 212.

${ }^{12}$ Svenaeus, 60. Jvf. Om blik og modernitet Johan Crary, Techniques of the observer: On vision and modernity in the nineteenth century (Cambridge, mass.: MIT Press 1999).

${ }^{13}$ Ludwig Jankau, "Die Photographie im Dienste der Medizin", Internationale medizinischphotographische Monatschrift 1894. Om „fotografiets mekaniske objektivitet" se Lorraine Daston \& Peter Galison, „The mage of objectivity“, Representations 40 (1992); jvf. Caroline A. Jones \& Peter Galison, eds, Picturing science, producing art (New York 1998); Solveig Jülich, Skugger av sanning: Tidig svensk radiologi och visuell kultur (under udgivelse).

${ }^{14}$ Svenaeus, 227. Obs, Svenaeus opponerer mod Leder ved at hævde at kroppen ikke er en skreven tekst, men en levende. Netop i denne dimension henter den sin mening. Dialogen i klinikken er talt snarere end læst. Altså; at forstå en patient er ikke at forstå et skerevet sprog, men et talt.

${ }^{15}$ Baron, ”why aren `t more doctors phenomenologists"?

${ }^{16}$ En klassisk kritik findes hos Jewson (1975). 


\section{Litteratur}

Auenbrugger, Leopold (1761): Inventum novum ex percussione thoracis bumani ut signo abstrusos interni pectoris morbos detegendi. Wien.

Borck, Cornelius (1996): Anatomien medizinischer Erkenntnis. In Borck (hrsg.): Anatomien medizinischen Wissens: Medizin, Macht, Moleküle. Frankfurt a.M: Fischer Verlag.

Crary, Jhan (1999):Techniques of the observer: On vision and modernity in the nineteenth century. Cambridge, mass.: MIT Press.

Cederschjöld, Pehr Gustaf (1836): Lärobok i vorden om qvinnans slägtlif. Stockholm.

Daston, Lorraine \& Peter Galison (1992): The image of objectivity. In Representations: 40

Davies, Robertson (1998): Can a doctor be a humanist?. In The merry heart: Reflections on reading, writing and the world of books. New York: Penguin Books.

Duffin, Jacalyn (1998): To see with a better eye:A life of R.T.H. Laennec. Princeton: Princeton University Press.

Fissell, Mary (1993): Innocent and honorable bribes: Medical manners in eighteenthcentury Britain. In Robert Baker et al ( eds.): The codification of medical morality. Dordrecht: Kluwer Academic Publishers.

Foucault, Michel (2000): Klinikekens fodsel. København: Hans Reitzel

Gilman, Sander: Touch, sexuality and disease. In Bynum \& Porter (ed.): Medicine and the five senses.

Grothjan, Martin (1945): Georg Groddeck and his teachning about man's innate needs for symbolisation. In Psychoanalytic review: 32, 9-24

Hegar, Alfred \& R. Klatnbach (1886): Die operative Gynäkologie mit Einschluss der Gynäkologischen Untersuchungslehre. Her 3. oplag, Stuttgart.

Ilmoni, Immanuel (1837): Om läkarens yrke och pligter. Helsingfors. Jacalyn Duffin, To see with a better eye: A life of R.T.H. Laennec (Princeton: Princeton University Press 1998), 135.

Jankau, Ludwig (1894): Die Photographie im Dienste der Medizin. In Internationale medizinisch-photographische Monatschrift

Jewson, Nicholas (1975): The dissapearance of the sick-man form medical cosmology. In Sociology:10, 225-244.

Johannison, Karin (1994): Den mörka kontinenten: Kvinnan, medicinen och fin-de-siécle. Stockholm: Norstedts.

Jones, Caroline \& Peter Galison (eds.) (1998) Picturing science, producing art. New York.

Jülich, Solveig (Under udgivelse): Skugger av sanning: Tidig svensk radiologi och visuell kultur.

King, Lester (1968): Signs and symtpoms. In Journal of the American Medical Association: 206: 5

Laennec, R.T.H. (1821): A treatise on disease of the chest.

Laennec, R.T.H (1829): De l'auscultation médiate ou Traité du diagnostic des poumons et du coeur,fondé principalement sur ce noveau moyen d'exploration. Paris.

Leder, Drew: A tale of two bodies: The Cartesian corpse and the lived body. In Leder (ed.) The body in medical thought and practise.

Leder, Drew (1990): Clinical interpretation: The hermeneutics of medicine. In Theoreticalmedicine: vol.11.

Mackenzie, James (1920): The future of medicine. Svensk oversættelse Medicinens framtid. Stockholm.

Mesterton, C.B. (1872-3): Om läkarens yrke och pligter. In Upsala läkareförenings förhandlinger, 
Kroppen i den moderne medicin - et historisk perspektiv på moderniteten

VIII:.

Nordström, Johan (1944-5): Från Magnus Huss`medicinska studieresa. Lychnos.

Porter, Dorothy \& Roy Porter, Patient's progress: Doctors and doctoring in the eighteenth-century England (Cambridge: Polity Press 1989).

Reiser, Stanley (1978): Medicine and the reign of technology. Cambridge: Cambridge University Press.

Philipp Sarasin (2001). In Divan: Tidskrift for psykoanalys och kultur, her efter Ingela Lind, Dagens nyheter, kronik 16/11.

Schmölders, Claudia (1995): Das vorurteil im liebe. Eine Einfürung in die Physiognomik.Berlin: Akademie Vorlag.

Svenaeus, Frederik (1999): The hermeneutics of medicine and the phenomenology of health: Steps towards a philosopby of medical practice. Linköbing

Theile, Friedrich (1885): Die physikalischen Untersuchungsmethoden. Weimar.

Trier, S. (1831): Om bröst-percussionen och den medelbara ausculationen. Berlin.

von Froriep, Ludwig Friedrich (1806, her 9. oplag 1832): Theoretisch-practisches Handbuch der Geburtshilfe. Weimar. 